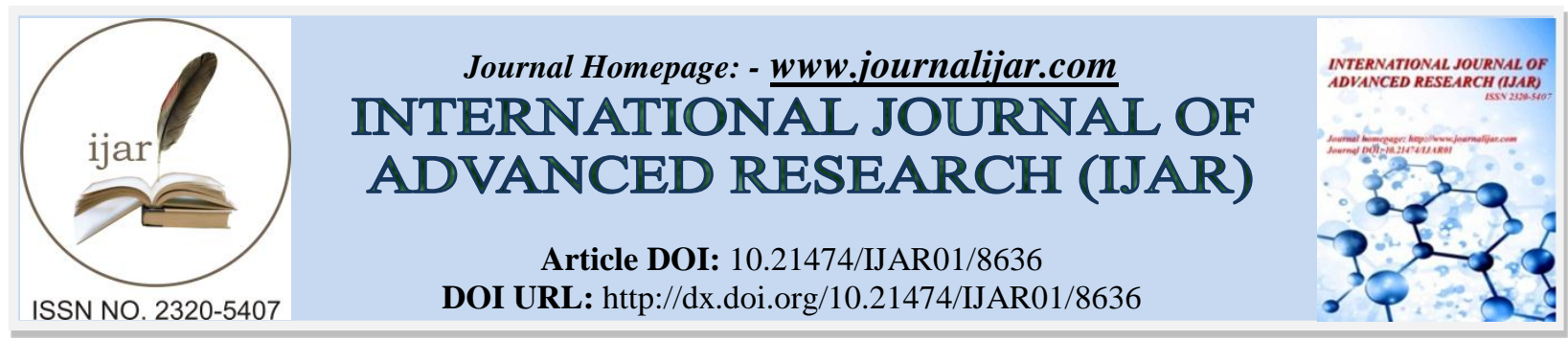

RESEARCH ARTICLE

\title{
A REVIEW ON BIOACTIVE SECONDARY METABOLITES OF SEAGRASS OF THE SOUTHERN RED SEA, ERITREA.
}

Mehari Ghebretinsae M. ${ }^{2}$, Awet Adhanom B. ${ }^{1}$, Henok Ghebremedhin G. ${ }^{1}$ and Biniam Tsegay B ${ }^{1}$.

1. Qualty control laboratory, Ministry of Marine Resources, Massawa- Eritrea.

2. Massawa College of Marine Science and Technology, Massawa- Eritrea.

\section{Manuscript Info}

Manuscript History

Received: 06 January 2018

Final Accepted: 08 February 2019

Published: March 2019

Key words:-

Seagrass, Medicinal value, Antimicrobial, Antioxidant.

Abbreviations: MMR (Ministry of

Marine Resources).

\section{Abstract}

Seas and oceans represent a big store of numerous marine organisms and offer an enormous source of many novel compounds. With the increasing trend in antimicrobial resistance, nowadays the uses of marine organisms for the production of pharmaceuticals are becoming interesting. In comparison to terrestrial, marine organisms possess very exigent, competitive and aggressive surrounding, which is very different in many aspects from the terrestrial environment. Such a situation demands them to produce quite specific and potent active molecules. Marine angiosperms especially seagrass are one of the shelters for a wide array of secondary metabolites like saponins, phlobatannins, phenols, amino acids, protein, tannins, flavonoids, terpenoids, Cardiac glycosides, phlobatannins, steroids, and phenols. Naturally, these seagrass are also used to produce compounds for a defense mechanism, which are found to be antioxidative in nature. The present review is thus focusing to present the pharmacological activities of eight marine seagrass species found in the Eritrean Red Sea for their antimicrobial and antioxidant properties.

Copy Right, IJAR, 2019. All rights reserved.

\section{Introduction}

Seagrass are one of the true marine flowering plants that belong to the group angiosperms [1]. They are known to produce a wide variety of secondary metabolites that aid as defense mechanism under stress conditions and these compounds are found to be anti-oxidative in nature [2]. These chemical compounds synthesized by secondary metabolic pathways are not involved in the normal growth, development or reproduction but usually have roles in adaptation processes under stress conditions [3]. These biogenic compounds or active metabolites like polyphenols, terpenoids and halogenated compounds produced by several species of the seagrass having anticancer (antitumor), antifungal or anti-inflammatory [4], antimicrobial [5], antiviral, antidiabetic activities [6], antimalarial, antioxidant [7], antiprotozoal, cytotoxic properties [8] which are effective in the prevention of different diseases having also other novel pharmacological activities.

Seagrass are eukaryotic organisms that live in salty water inhabiting soft bottoms, shallow water areas of temperate, subtropical, tropical seas with an exception of polar regions [9] and are recognized as a potential source of bioactive natural products. Their distribution ranges up to a depth of around 50-60 $\mathrm{m} \mathrm{[10].} \mathrm{The} \mathrm{term} \mathrm{seagrass} \mathrm{has} \mathrm{been} \mathrm{used}$ for long by the Germans to refer undoubtedly to a grass like habitat. They are depicted to be evolved approximately 
100 million years ago from land plants that returned to the sea in a least three separate lineages or families [12]. Moreover the term seagrass was probably introduced into the scientific literature by the first researcher Ascherson (1871), as reported by C. den Hartog, 2006 [11]. Importantly, Seagrass have a long history of being used for a variety of remedial purposes such as fever, skin diseases, muscle pains, wounds, and stomach problems, against stings of different kinds of rays, tranquillizers for babies [6] and for diabetes mellitus [12]. Besides of their pharmacological importance marine seagrass can also be used as a food (nutritious seeds), fertilizer (nutrient rich biomass), livestock feed (goats and sheep), packing material to transport fragile items and to ship fresh fish from the coast to cities $[\mathbf{1 0}]$.

In the sea, 3 types of plants occur: phytoplankton, seaweeds and seagrass. Seagrass are mostly found attached to the substrate with most restricted to sand habitats [13]. They form highly productive and dynamic ecosystems [14], which rank among the most productive ecosystems of the ocean [12]. These flowering plants have true roots, rhizomes or vertical stem, leaves that are interconnected by vascular system [15]. They belong to superorder Alismatiflorae (Monocotyledonae) in the plant kingdom. Globally there are about 72 species of seagrass distributed worldwide [3]. Of which 13 species of seagrass are known from the Western Indian Ocean, while 12 of them are found extending in the Red Sea [16]. Seagrass are classified into four families based on their morphological, anatomical and reproductive structure, namely Hydrocharitaceae, Zosteraceae, Cymodoceaceae, and Posidoniaceae $[11]$.

\section{Seagrass in Eritrea}

Eritrea is located in between $1245^{\prime} \mathrm{N}$ and $1803^{\prime} \mathrm{N}$ latitude, and, $3735^{\prime} \mathrm{E}$ and $4307^{\prime} \mathrm{E}$ longitude. It possesses a mainland coastline of more than $1350 \mathrm{~km}$ along the south-western coast of the Red Sea. The Eritrean coastline stretches from its northern border with Sudan at Ras Kesar to its southern border with Djibouti at Ras Dumera and is endowed with biodiversified marine biota. In addition, the Red Sea of Eritrea contains more than 350 islands that form a shoreline of more than $1,950 \mathrm{~km}$. The geographical extent of the Eritrean landmass is estimated about $124,000 \mathrm{~km}^{2}$ and its territorial water covers an area of about $55,000 \mathrm{~km}^{2}$ [17].

According to the Israeli expeditions done by Y. Lipkin and P.C. Silva (2002), the Eritrean Red Sea comprises 4 species of seagrass, representing 3 genera, namely Thalassodendron ciliatum, Halophila ovalis, Halophila stipulacea, and Thalassia hemprichii [18].

Further Researches done by Price et al. (1988) depicts that out of the 72 seagrass species found in the world, 11 species are available in the southern and central Red Sea [19]. Unpublished data of MMR shows that 8 out of the 11 seagrass species were identified in the Eritrean Red Sea, namely Halophyla ovalis, Halophyla stipulacea, Thalassia hempricae, Halodule uninervis, Syringodium isoetifolium, Thalassodendron ciliatum, Enhalus acoroides and Cymodecia rutandata. In addition, they reported that no significant geographical variation was observed among these species.

\section{Antimicrobial Activity of Seagrass}

The marine species from the sea offers a huge number of novel compounds, and it portrays a plethora of natural molecules to be evaluated for drug and other therapeutic activity [20].

Nehad M. Gumgumje et al. (2018) tested the antibacterial activity of different solvent extracts of Halodule uninervis against different bacterial pathogens such as Bacillus subtilis, Methicillin-Resistant Staphylococcus aureus (MRSA), Staphylococcus aureus, Micrococcus luteus, Escherichia coli, Klebsiella pneumonia, and Pseudomonas aeruginosa. Among them the ethanol leave extract of Halodule uninervis showed the strongest activity against Pseudomonas aeruginosa, while displaying the lowest activity against Staphylococcus aureus. Every solvent extract have shown activity against one or more of the selected bacterial pathogens, except the aqueous extract had exhibited no kind of inhibition with an exception to $P$. aeruginosa exhibiting at $14.67 \mathrm{~mm}$ zone. In general the result showed that the ethanolic leave extracts of seagrass $H$. uninervis gave better performance than other solvent extracts [5].

R. Karthikeyan and M.Sundarapandian (2017) tested the methanolic extract of H. uninervis plant in streptozotocin induced diabetic rats. The diabetic rats were administered orally with $H$. uninervis methanolic extract at two different doses (150 and $250 \mathrm{mg} / \mathrm{kg}$ b.wt./day) for 18 days and have showed a significant antidiabetic activity and improvements in hepatic and renal function. At dose levels of 150 and $250 \mathrm{mg} / \mathrm{kg}$, glucose levels were decreased by $24.8 \%$ and $29.9 \%$ at the $6^{\text {th }}$ hour, respectively. Antidiabetic effect of the extract was slightly decreased at the $8^{\text {th }}$ 
hour, but remained statistically significant. An overall reduction of $26 \%$ was observed on the $18^{\text {th }}$ day by $50 \mathrm{mg} / \mathrm{kg}$ administration $(p<0.01) .52 .5 \%$ reduction of glucose level in the serum observed at $18^{\text {th }}$ day administration at dose level of $150 \mathrm{mg} / \mathrm{kg}(\mathrm{p}<0.0001) .250 \mathrm{mg} / \mathrm{kg}$ extract administration is more effective from $6^{\text {th }}$ day onwards with a reduction rate of $18.9 \%(\mathrm{p}<0.01)$ and maximum reduction of serum glucose level by $61.9 \%$ on the $18^{\text {th }}$ day. In addition the presence of saponin glycosides, steroids, and phenolic compounds in the phytochemical study of the extracts was inferred to be a reason for the good activity of extracts [2].

Likewise endophytic fungi isolated from seagrass Cymodocea serrulata, Halophila ovalis and Thalassia hemprichii of southern Thailand were screened for their antimicrobial activity against ten human pathogenic microorganisms by a colorimetric broth microdilution test. They obtained 160 endophytic fungi from these three seagrass species, of which $69 \%$ of the isolates have exhibited antimicrobial activity against at least one test strain. Isolates like Penicillium sp. PSU-ES43, Fusarium sp. PSU-ES73, Stephanonectria sp. PSU-ES172 and an unidentified endophyte PSU-ES190 from T. hemprichii have shown to possess strong antimicrobial activity against human pathogens with minimum inhibitory concentrations (MIC), less than $10 \mu \mathrm{g} / \mathrm{m}$. The most active genera found in this study were Fusarium, Penicillium, Stephanonectria and Trichoderma. The overall results have established that seagrass are a good source of antimicrobial producing endophytic fungi [21].

Furthermore, Larvicidal activity of four seagrass species viz. Halophila ovalis (AUOCAS025), Enhalus acorodies (AUOCAS026), Thalassia hemprichii (AUOCAS027) and Halodule pinifolia (AUOCAS028) from Mandapam, South East Coast of India, have shown a pronounced activity as a leading mosquito control. However, the leaf ethanolic extracts of Thalassia hemprichii and $H$. pinifolia showed no mortality against the tested larva A. aegypti $[22]$.

Moreover, Saranya K. et al. (2017) found that the Seagrass H. ovalis and T. hemprichii collected from Keelakarai Coast, Ramnad-Tamil Nadu have an interesting biochemical and bioactive potential. The investigation delves upon phytochemical screening, biochemical evaluation and antibacterial activity of the selected seagrass species. Conversely phytochemical screening of $H$. ovalis and $T$. hemprichii showed the presence of tanins, terpenoids and steroids. Whereas the water extract of $H$. ovalis contains saponnins, phlobatannins, phenols, amino acids and proteins. Ethanol extract of $T$. hempirichii endorses the presence of tannins, flavonoids, terpenoids, Cardiac glycosides, phlobatannins, steroids and phenols. The water extract of $T$. hempirichii showed the presence of amino acids and proteins. Antibacterial bioassay of ethanoloic extract of $H$. ovalis showed maximum inhibitory activity against Klebsiella pneumoniae followed by Bacillus subtilis, Staphylococcus aureus and Escherichia coli. Maximum antibacterial activity was observed against Escerichia coli and Staphylococcus aureus. Maximum activity showed in Bacillus subtilis and minimum activity found in Staphylococcus aureus in water extract of H. ovalis. Besides, both $H$. ovalis and T. hemprichii have shown to exhibit a biochemical composition of Protein (6.7\%), Carbohydrate (9.2\%), Lipid (1.39\%), Fiber (17.6\%) and Ash (32.2\%); and Protein (7.8\%), Carbohydrate (9.4\%), Lipid $(1.81 \%)$, Fiber (18.6\%) and Ash (36.5\%) respectively. Altogether these researches have shown considerable amount of nutritional and bioactive potential of these species [4].

Research on antimicrobial and antioxidant activities of the tropical Seagrass, Halophila stipulacea, from ElBardawil Lake, Egypt, was investigated by Howayda et al. (2012). Methanolic extract showed 40\% antioxidant activity and aqueous extract of $H$. stipulacea was active against Gram positive bacteria (Bacillus subtilis), yeast (Candida albicans) and fungi (Aspergillus niger) with inhibition zone 15, 15 and $20 \mathrm{~mm}$, respectively. Whereas the extract was not active against Gram negative bacteria, Escherichia coli and Pseudomonas aeruginosa. In comprise to their antimicrobial activity the total phenolic extract was found to be $0.523 \mathrm{mg}$ tannic acid per gram, which are reported to be responsible for the antioxidants and free radical scavengers potential of the seagrass. According to McMillan et al. (1980) the presence of unidentified sulphated phenolic compounds from H. stipulaceae has been reported [23].

In other research, antibacterial potential of three seagrass species extracts, Halophila stipulacea, Cymodocea serrulata and Halodule pinifolia, was tested against seven human bacterial pathogens viz S. Bodii, V. Cholerae, K. Pneumonia, S. Dysentriae, P. Eruginosa, S. paratyphii and S. Aureus using methanol, Hexane and chloroform solvents. Methanolic and chloroform extracts of all the three seagrass were active against all the tested pathogens, of which methanol extracts were more active. Whereas the hexane extract of all seagrass was not active against Staphylococcus aureus. Moreover hexane extract of $C$. serrulata was also not active against $V$. cholerae, S. paratyphi and $K$. pneumoniae. The highest zone of inhibition $(11 \mathrm{~mm})$ was recorded in methanol extract of $H$. 
stipulacea against $S$. dysenteriae with MIC value of $100 \mu \mathrm{g} / \mathrm{mL}$ followed by (8 mm) with $H$. pinifolia and chloroform extract of $C$. serrulata against $K$. Pneumonia. Of the three seagrass species screened for their antibacterial activity in the investigation, $H$. pinifolia and $H$. stipulacea were more superior to $C$. serrulata against the human pathogens in controlling the microbial growth [24].

The antibacterial, antioxidant, and anti-inflammatory activities of methanolic extracts of $H$. ovalis were investigated. Methanol extract inhibited the growth of Bacillus cereus at a minimum inhibitory concentration of $50 \mu \mathrm{g} / \mathrm{mL}$ and other Gram-negative pathogens at $75 \mu \mathrm{g} / \mathrm{mL}$, except Vibrio vulnificus. Reducing power and total antioxidant level increased with increasing extract concentration. H. ovalis exhibited strong scavenging activity on 2,2-diphenyl-1picrylhydrazyl (DPPH) and superoxide radicals at IC50 of 0.13 and $0.65 \mathrm{mg} / \mathrm{mL}$, respectively. Methanol extract of $H$. ovalis showed noticeable anti-inflammatory activity at IC50 of $78.72 \mu \mathrm{g} / \mathrm{mL}$. The GC-MS analysis of $H$. ovalis revealed the presence of triacylglycerols as major components in purified fractions. Quantitative analysis of phytochemicals revealed that seagrass $H$. ovalis are rich in phenols. These findings demonstrated that the methanol extract of $H$. ovalis exhibited appreciable antibacterial, noticeable antioxidant, and anti-inflammatory activities, and thus could be used as a potential source for natural health products [9].

Antibacterial properties of the three seagrass, namely Cymodocea serrulata, Halophila ovalis and Zostera capensis were tested against the human pathogens Staphylococcus aureus, Bacillus cereus, B. subtilis, Escherichia coli, Salmonella paratyphi, Salmonella typhimurium and Micrococcus luteus, using six different solvents, namely petroleum ether, chloroform, ethyl acetate, acetone, methanol and water. Ethyl acetate extracts of all the seagrass were active against all gram-positive and most of the gram-negative pathogens tested, namely Staphylococcus aureus, Bacillus cereus, B. subtilis, Salmonella typhimurium and Micrococcus luteus; and methanolic extracts active against Staphylococcus aureus, Salmonella paratyphi, S. typhimurium and Micrococcus luteus. Maximum activity was recorded in ethyl acetate extract of Halophila ovalis, followed by methanolic extract of Zostera capensis. Acetone, petroleum ether and chloroform showed less activity. Minimum Inhibitory Concentrations of methanol and ethyl acetate extracts of the three seagrass showed maximum activity against all the six pathogens. Of the three seagrass studied, minimum concentrations of Halophila ovalis extracts were effective in controlling the growth of Micrococcus luteus, Escherichia coli and Salmonella typhimurium. Of the three different seagrass examined in the present study $H$. ovalis and Zostera capensis were more effective than Cymodocea serrulata in controlling the growth of all pathogens except Micrococcus luteus. Fifty percent of activity was recorded in $H$. ovalis followed by Z. capensis (45.2\%) and Cymodocea serrulata (44.1\%). Ethyl acetate has proved to be the best solvent for isolation of bioactive substances from seagrass $(81.9 \%)$ followed by methanol $(76.2 \%)$ [25].

Researches done by J.Sangeetha and S.Asokan(2016) on antibacterial activities of three seagrass species extracts viz. Cymodocea serrulata, Halophila ovalis and Halodule pinifolia were tested against ocular pathogens E.coli, Enterococcus faecalis, Corynebacterium, Bacillus subtilis, Pseudomonas aeruginosa, Klebsiella pneumonia, Methicillin Sensitive Staphylococcus aureus, Methicillin Sensitive Staphylococcus saphrophyticus and Methicillin Sensitive Staphylococcus epidermidis using different solvents such as hexane, ethyl acetate, chloroform and ethanol. It was reported that $C$. serrulata, $H$. ovalis and $H$. pinifolia extracts have showed antibacterial activity against some ocular pathogens, while the control disks (DMSO) showed no inhibition. The negative control antibiotic amikacin inhibited all the pathogens. The extracts obtained using chloroform, Ethyl acetate and Ethanol of the three seagrass showed maximum activity against E.coli $(8.66 \mathrm{~mm}, 9 \mathrm{~mm}$ and $7.33 \mathrm{~mm} ; 8.33 \mathrm{~mm}, 9 \mathrm{~mm}$ and $8 \mathrm{~mm}$; and $7.6 \mathrm{~mm}, 7.3 \mathrm{~mm}$ $7 \mathrm{~mm}$ ) and Corynebacterium sps (7mm, 8mm; 13.66mm, 11 mm, 14.33mm; and 11.66mm, 13mm 14.66mm) respectively. No zones of inhibition were recorded for the remaining six pathogens in all the extracts. Of the three seagrass studied, minimum inhibitory concentrations of Halodule pinifolia extracts were effective in controlling the growth of Corynebacterium species and Cymodocea serrulata extracts in E.coli. H. ovalis extracts were effective in controlling the growth of Corynebacterium sps [20].

Vietnam and Indian seagrass species Enhalus acoroides, Halophila ovalis and Halodule pinifolia were studied for mediating non-lethal interactions on sessile bacterial (E.coli) and fungal (Candida albicans) cultures. The focus was mostly on anti-biofilm activity of the seagrass extracts without killing cells. Seagrass extracts seem to be more effective in preventing microbial adhesion on hydrophobic surfaces. The results showed that non-lethal concentrations of $E$. acoroides leaf extract: reduce bacterial and fungal coverage by 60.9 and $73.9 \%$ respectively; affect bacterial biofilm maturation and promote dispersion, up to $70 \%$, in fungal biofilm; increase luminescence in Vibrio harveyi by $25.8 \%$. In addition it was reported that E. acoroides leaf extract proved to be the most promising extract among those tested. Indeed, the selected non-lethal concentrations of E. acoroides leaf extracts were having 
ant-biofilm effect on C. albicans and E.coli biofilm in the first phase of biofilm formation, opening up the possibility of developing preventive strategies to hinder the adhesion of microbial cells to surfaces [26].

According to R. Chithra Roy Angel et al.(2015) the seagrass sps S.isoetifolium was extracted by three solvents: methanol, chloroform and acetone. The extracts were tested against 6 fungal spp Aspergillus fumigatus (MTCC 4333), Aspergillus niger (MTCC 961), Rhizomucor miehei (MTCC546), Candida glabrata (MTCC 3984), Candida albicans (MTCC 183) and Candida tropicalis(MTCC 184). Methanol extract has shown maximum activity against C. tropicalis $(12 \pm 0.96 \mathrm{~mm})$, while minimum activity was recorded by acetone extract against A. fumigatus $(5 \pm 0.22 \mathrm{~mm})$. Eventually, they concluded that methanol extracts of S.isoetifolium have shown a remarkable antifungal activity. Phytochemical analysis of the methanol extract of the S.isoetifolium has shown the presence of saponins, resins, protein, carbohydrate, glycosides, phenols and alkaloids, while tannins, sterols, terpenoids, steroids, catachols and flavonoids were absent. Moreover methanolic, chloroform and acetone extract of seagrass S.isoetifolium were tested against 17 human and 5 fish pathogens. Acetone extract has shown better activity against S.paratyphi (6mm), S.dysentriae (7mm), P.fluorescence $(6 \mathrm{~mm})$, B.subtilus $(7 \mathrm{~mm})$, and V.chlorae $(7 \mathrm{~mm})$, while least activity was recorded against V.chlorae $(4 \mathrm{~mm})$ and P.fluorescence $(3 \mathrm{~mm})$ by methanolic extracts. In addition good insecticidal activity was exhibited by acetone extract. To recap the overall result conveys S.isoetifolium is an interesting source of antimicrobial activity [27].

Ragu pathi Raja kannan et al.(2013) reported C. rotundata have coumarins, flavonoids, phenol, proteins, free amino acids, quinones, saponins, sterols, sugars, terpenoids bioactive compounds with antibacterial, cytotoxic and haemolytic activities [28]. According to Mani et al. (2012) C.rotundata has antibacterial activity due to the presence of the bioactive compounds tannin, saponins, resin, protein, acidic compounds, reducing sugars, terpenoids, cardiac glycosides and alkaloids [29].

C.rotundata and S.isoetifolium contains large amount of bioactive compounds like saponins, flavonoids and alkaloids, so they are suspected to have pharmacological role $[\mathbf{3 0}, \mathbf{3 1}]$. The methanolic extract of both seagrass was tested against Sitophilus oryzae and Sitophilus zeamais. The result showed $96.5 \%$ and $86.5 \%$ mortality at a volume of $500 \mu \mathrm{l}$ for $24 \mathrm{hrs}$ respectively. On the other hand methanolic extract S.isoetifolium has shown $100 \%$ mortality

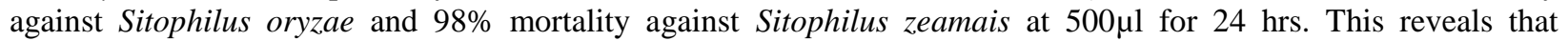
C.rotundata and S.isoetifolium have a great potent of insecticidal property [32].

Methanolic extract of $S$. isoetifolium and $C$. rotundata were tested against gram-positive bacteria and fungi. The investigation also explored the preliminary phytochemical analysis of the active biogenic compounds. Tannins, terpenoids, saponins, phenols, Alkaloids and glycosides were present in both S.isoetifolium and C.rotundata, while Flavonoids and steroids were only present in C.rotundata. Antimicrobial analysis of C.rotundata have shown maximum activity against the $\mathrm{G}^{+}$Staphylococcus aureus $(17 \mathrm{~mm}), \mathrm{G}^{-}$Escherichia coli $(15 \mathrm{~mm})$ and fungi, Aspergillus niger $(15 \mathrm{~mm})$. On the other hand S.isoetifolium showed maximum activity against $\mathrm{G}^{+}$Staphylococcus aureus $(15 \mathrm{~mm}), \mathrm{G}^{-}$Escherichia coli $(8 \mathrm{~mm})$ and fungi, Aspergillus niger $(12 \mathrm{~mm})$. Overall, higher antimicrobial activity was seen by C.rotundata to S.isoetifolium. This was suggested due to lack or presence of traces of saponins, tannins, phenolic compounds and flavanoids which are responsible for the antimicrobial action [31].

The ethanol extract of $C$. rotundata has shown lower antibacterial activity against Shigella $(7 \mathrm{~mm})$ and P.fluorescence $(7 \mathrm{~mm})$ when compared to the positive control streptomycin sulphate $(9 \mathrm{~mm})$. Conversely the butanolic extract showed maximum activity against $S$. aerous $(6 \mathrm{~mm})$ followed by $P$. vulgaris $(5 \mathrm{~mm})$. Tannins, saponins, resins, proteins, acidic compounds, reducing sugars, terpenoids, cardiac glycosides and alkaloids were present in phytochemical analysis of the ethanolic and methanolic extracts, but phenols, steroids, catachols and flavonoids were absent [33].

Five flavonoids (rutin, asebotin, 3-hydroxyasebotin, quercetin-3-O- $\beta$-D-xylopyranosidae and a racemic mixiture of catechin) and caffeic acid were isolated and identified for the first time from seagrass T.ciliatum. The crude methanolic extract and the isolated pure compounds were evaluated for their cytotoxic activities against HCT-116, HEPG, MCF-7 and He La human cancer cell lines, antiviral activity against HSV and hepatitis A virus, and antioxidant activity. The DPPH free radical scavenging activity of the T.ciliatum was $(71 \pm 1.09 \%)$ at $1 \mathrm{mg} / \mathrm{ml}$. In addition rutin showed higher free radical scavenging activity with an E50 value of $0.99 \mathrm{~mm}$ than quercetin-3-O- $\beta$-Dxylopyranosidae $(1.63 \mathrm{~mm})$, 3-hydroxyasebotin, caffeic acid and racemic mixiture of catechins, while asebotin is inactive. The crude extract exhibited cytotoxic activity against HCT-116, HEPG, MCF-7 and He La human cancer 
cell lines with IC50 values of (4.2 \pm 0.51$)(8.12 \pm 0.34)(4.12 \pm 0.77)$ and $(9.8 \pm 0.25) \mu \mathrm{g} / \mathrm{ml}$ respectively. Quercetin-3-O$\beta$-D-xylopyranosidae showed higher activities against HEPG cells, (7.25 \pm 0.39$) \mu \mathrm{m}$, and HCT116 cells, $(11.17 \pm 0.39) \mu \mathrm{m}$. 3-hydroxy asebotin was active against HPEG cells, $(8.55 \pm 0.42) \mu \mathrm{m}$. 3-hydroxy biotin and the racemic mixiture of catechin exhibited cytotoxic activity against HCT-116 cell lines only. None of the isolated compounds showed activity against $\mathrm{He}$ La and MCF-7 cancer cell lines [34].

Dihydrochaleone diglycoside has been isolated from the EtOAc of the Egyptian seagrass T.ciliatum. The antiinfluenza A virus activity of the new compound and asebotin was evaluated. The obtained result have shown that the inhibition doze concentration of asebotin was more than that of Thalassedendrone with IC50 = 2.00 and $1.96 \mu \mathrm{g} / \mathrm{ml}$ respectively, and the cytotoxic concentration (CC50) of 3.36 and $3.14 \mu \mathrm{g} / \mathrm{ml}$ respectively [35].

\section{Antioxidant Activity of Seagrass}

Studies have shown that there is a positive correlation between the increased dietary intake of natural antioxidants and the reduced coronary heart disease, cancer mortality, and longer life expectancy. Halophila ovalis, Syringodium isoetifolium and Halodule pinifolia have antioxidant property due to the presence of phenolic compound [36].

Danaraj Jeyapragash et al. (2016) evaluated the antioxidant activity of methanolic extracts from the rhizome and leave portion of six seagrass species. Among evaluated species higher DPPH radical scavenging activity was found in leaf $(78.84 \pm 0.87)$ and rhizome extracts $(75.480 \pm 0.97)$ of $C$. rotundata and the lowest scavenging activity was found in the leaf and rhizome extracts of $H$. ovate $(12.01 \pm 0.63$ and $5.769 \pm 1.14)$. Generally, maximum phenolic content and antioxidant activity were shown by $C$. rotundata followed by $H$. uninervis [37].

Ragupathi Raja Kannan et al. (2013) reported that Cymodocea rotundata contains Phenol, Flavonoids, Tannin, Vitamin C, Vitamin E, and Characterized Phenolic compound ( $p$-coumaric acid) which have an antioxidant property [38].

Ace Baehaki et al. (2016) investigated the phytochemistry and antioxidant activity of the methanol extracts from Halodule uninervis. It was found that the methanol extract of these seagrass produces interesting phytochemical compounds: flavonoids, alkaloids, steriod and phenols. While the free radical scavenging potential (DPPH method (IC50)) and the highest reducing power of H.uninervis was found to be $1.575 \mathrm{ppm}$ and 1.381 ppm respectively. In addition they have suggested that the free radical scavenging activity of $H$. uninervis could be due to their high content of flavonoids components which interrupts the propagation of autoxidation by donating hydrogen atom of some hydroxyl $(\mathrm{OH})$ bases that are attached outside the benzene rings, resulting in the formation of stable free radical [7].

Neelima (2015) determined the antioxidant radical scavenging activity of seven seagrass species from Mandapam coast of South India. Ethyl acetate extracts fractions of Thalassia hemprichii have exhibited high DPPH radical scavenging activity (94.34\%), which is comparable to the positive controls highest being 95.6 \pm 0.94 . This ascertained that, this activity is due to the presence of phenolic compounds which act as free radical scavengers and antioxidants. While the the aqueous fractions showed little or negligible DPPH scavenging activity that suggestes the active DPPH radical scavengers of these seagrass are seem to be found in the polar and semi polar extract in nature [39].

Methanolic extract of C.rotundata was evaluated to have the smallest value in comparison to three solvents (nhexane, ethyl acetate and methanol). Methanol has found to be the best solvent for the extraction of phenols, while n-hexane has the lowest and ethyl acetate moderate extraction capacity. So the methanol extract of T.hempricii has large amount of phenol content, and the lowest n-hexane extract for the C. rotundata. In general methanol is able to extract the component phenol in high quantities, as ethyl acetate solvent produced high quantities in S.isoetifolium. Strongest DPPH radical scavenging activity was observed in ethyl acetate extract of S.isoetifolium with 96.34 ppm. The methanol extract of T.hempricii, C.rotundata and E.acoroides has DPPH radical scavenging activity of 214.68, 123.72 and115.79 ppm respectively. Besides, higher fiber content was registered by the spp E.acoroides $(8.93 \mathrm{~g} / 100 \mathrm{gm})$ and lowest content by S.isoetifolium $(621 \mathrm{gm} / 100 \mathrm{gm})$. To wrap up all the seagrass spp have shown a promising antioxidant property [40].

Eight seagrass spp were tested for the search of safe and cheap antioxidant source. As a result, higher antioxidant activity was observed in $H$. pinifolia, H. stipulacea, and C. serrulata of 132.382, 75.027, and $32.415 \mathrm{mg}$ ascorbic 
acid equivalent/g respectively. When tested by thin layer chromatography, $H$. pinifolia showed strong antioxidant activity. Higher DPPH radical scavenging activities were recorded in $H$. pinifolia $(68.066 \%)$ followed by $H$. stipulacea $(67.413 \%)$ and $C$. serrulata $(61.853 \%)$. The minimum DPPH radical scavenging activity was recorded in H. ovata (16.926\%). The scavenging effect of standards on the DPPH radical decreased in the order: ascorbic acid > gallic acid, which was 57.28 and $55.753 \%$, respectively. Highest ability for reducing $\mathrm{Fe}^{3+}$ was observed in $H$. stipulacea $(46.289 \pm 1.002)$, and $H$. pinifolia(42.611 \pm 0.800$)$ compared to the other seagrass studied. Finally, from this particular study it has been concluded that seagrass have strong antioxidant properties due to the total phenolic content [41].

\section{Conclusion}

The Eritrean Red Sea contains diversified seagrass species which possess a plethora of bioactive compounds that can be candidates for drug development and other purposes. Hence, extensive research is required in these areas to create a safe and better future.

\section{References}

1. Jo Foden, D.P. Brazier.2007. Angiosperms (seagrass) within the EU water framework directive: A UK perspective. Marine Pollution Bulletin, 55, 181-195.

2. R. Karthikeyan, M.Sundarapandian.2017. Antidiabetic Activity of Methanolic Extract of Halodule uninervis in Streptozotocin-Induced Diabetic Mice. Pharm. Sci. \& Res. Vol. 9(10), 1864-1868, ISSN: 0975-1459.

3. Ponnambalam Subhashini, Elangovan Dilipan, Thirunavukkarasu Thangaradjou, and Jutta Papenbrock.2013. Bioactive natural products from marine angiosperms: abundance and functions. Nat. Prod. Bioprospect, 3 , 129-136.

4. Saranya K, Balamani K, Kokila P, Maruthupandian A and Viji M. 2017. Biochemical and bioactive potential of seagrass Halophila ovalis (R. Brown) J.D. Hooker and Thalassia hemprichii (Ehrenb. Ex solms) Asch. International Journal of Advances in Interdisciplinary Research, Vol. 4 Issue 3 Pages: 51-55 ISSN 2348 0696.

5. Nehad M. Gumgumjee, Duaa A. Bukhari, Wafa A. Alshehri and A S. Hajar. 2018. Antibacterial activity of Halodule uninervis leaves extracts against some bacterial pathogens strains. Pharmacophore. 9(2), Pages: 5259, ISSN: 2229-4042.

6. Rengasamy Ragupathi Raja Kannan, Radjassegarin Arumugam, Perumal Anantharaman. 2012. Chemical composition and antibacterial activity of Indian seagrass against urinary tract pathogens. Food Chemistry, 135: 2470-2473.

7. Ace Baehaki, Agus Supriadi, Muhammad Cahya Pratama. 2016. Antioxidant Activity of Methanol Extract of Halodule uninervis Seagrass from the Coastal of Lampung, Indonesia. Research Journal of Pharmaceutical, Biological and Chemical Sciences, ISSN: 0975-8585.

8. Edmund P. Green \& Frederick T. Short. 2003. World Atlas of Seagrass. UNEP World Conservation Monitoring Centre. UNEP-WCMC, ISBN 0-520-24047-2.

9. N. Yuvaraj, P. Kanmani, R. Satishkumar, A. Paari, V. Pattukumar, and V. Arul. 2012. Seagrass as a potential source of natural antioxidant and anti-inflammatory agents. Pharmaceutical Biology, 50(4): 458-467, ISSN 1388-0209.

10. Jens Borum, Carlos M. Duarte, Dorte Krause-Jensen and Tina M. Greve. 2004. European seagrass: an introduction to monitoring and management. $M \& M S$ project, ISBN: 87-89143-21-3.

11. C. den Hartog, John Kuo.2006. Taxonomy and Biogeography of Seagrass. Springer. Biology, Ecology and Conservation, pp. 1-23.

12. N. Pushpa Bharathi, P. Amudha AND V. Vanitha. 2016. Seagrass - novel marine nutraceuticals. Int J Pharm Bio Sci; 567 - 573, ISSN 0975-6299.

13. Len McKenzle.2008.seagrass educators hand book, seagrasswatch, pp 1-20.

14. www.seagrasswatch.org

15. F. Short, T. Carruthers, W. Dennison, M. Waycott. 2007. Global seagrass distribution and diversity: A bioregional model. Journal of Experimental Marine Biology and Ecology 350, 3-20.

16. Amgad El Shaffai.2011.A field guide to seagrass of Red Sea. IUCN, Gland, Switzerland and Total Foundation, Courbevoie, France, ISBN: 978-2-8317-1414-1.

17. Rebecca Klaus. 2015. Coral Reefs and Communities of the Central and Southern Red Sea (Sudan, Eritrea,Djibouti, and Yemen) Springer Earth System Sciences, pp 409-426. 
18. Lipkin, Y. \& P.C. Silva .2002. Marine algae and seagrass of the Dahlak Archipelago. Southern Red Sea. Nova Hedwigia, 75: 1-90.52.

19. Price A.R.G, Crossland C. J., Dawson Shepherd A.R., Mc Dowall R.J., Medley P.A.H., Stafford Smith M.G., Ormond R.F.G. and Wrathall T.J.1988. Aspects of seagrass ecology along the Eastern coast of the Red Sea. Botanica Marina, 31: 83-92.

20. J. Sangeetha and S.Asokan.2016. Phytochemical analysis and antibacterial activity of the three different seagrass extracts. International Journal of Advanced Research. Volume 4, Issue 5, 1451-1457, ISSN 23205407.

21. Preuttiporn Supaphon, Souwalak Phongpaichit, Vatcharin Rukachaisirikul, Jariya Sakayaroj.2013. Antimicrobial Potential of Endophytic Fungi Derived from three Seagrass Species: Cymodocea serrulata, Halophila ovalis and Thalassia hemprichii, PLOS ONE, Vol-8 Issue 8 pp 1-9.

22. M.Syed Ali, S.Ravikumar and J. Margaret Beula.2013. Larvicidal potential of seagrass extracts against dengue vector aedes aegypti (insecta: diptera: culicidae). Int J Pharm Bio Sci. 4(2): (P) 62 - 67, ISSN 09756299.

23. Howayda, H. Abd El-Hady, Eman, R. Hamed and Abeer, N. Shehata.2012. Molecular Identification, Antimicrobial and Antioxidant Activities of the Tropical Seagrass Halophila stipulacea Grown in ElBardawil Lake, Egypt. Australian Journal of Basic and Applied Sciences, ISSN 1991-8178.

24. Rengasamy Ragupathi Raja Kannan, Rajasekaran Arumugam, Perumal Anantharaman .2010. Antibacterial potential of three seagrass against human pathogens. Asian Pacific Journal of Tropical Medicine. 890-893.

25. Chinnadurai Sreenath Kumar Dronamraju V. L. Sarada Thomas Paul Gideon Ramasamy Rengasamy.2008. Antibacterial activity of three South Indian seagrass, Cymodocea serrulata, Halophila ovalis and Zostera capensis. World J Microbiol Biotechnol, 24:1989-1992.

26. Luca De Vincenti, Yvana Glasenapp, Cristina Cattò, Federica Villa1, Francesca Cappitelli and Jutta Papenbrock.2018. Hindering the formation and promoting the dispersion of medical biofilms: nonlethal effects of seagrass extracts. Complementary and Alternative Medicine, 18:168.

27. R.Chithra Roy Angel and G.Uma Maheswari. 2015. Evaluation of antifungal activity of Syringodium isoetifolium against selected fungal pathogens. International journal of multidisciplinary research, vol.1, issue -9 .

28. Ragupathi Raja Kannan R, Arumugam R, Iyapparaj P, Thangaradjou T, Anantharaman P. 2013. In vitro antibacterial, cytotoxicity and haemolytic activities and phytochemical analysis of seagrass from the Gulf of Mannar, South India. Food Chem, 136: 1484-1489.

29. Mani AE, Bharathi V, Patterson J. 2012.Antibacterial Activity and Preliminary Phytochemical Analysis of Sea Grass Cymodocea rotundata. Int J Microbiol Res; 3 (2): 99-103.

30. S. Ravikumar, M. Gnanadesigan, A. Saravanan, N. Monisha, V. Brindha, S. Muthumari. 2012. Antagonistic properties of seagrass associated Streptomyces sp. RAUACT-1: A source for anthraquinone rich compound. Asian Pacific Journal of Tropical Medicine, 887-890.

31. Joys Selva Mary Albert, Gayathri K and R. Sornaraj.2015.A ssessment and screening of phyto-chemical components of the seagrass cymodocea rotundata and syringodium isoetifolium and its antibiotic potential. International Journal of Institutional Pharmacy and Life Sciences, (ISSN): 2249-6807.

32. Joys Selva Mary Albert and R.Sornaraj. 2015. Evaluation of Insecticidal activity of the selected seagrass Cymodocea rotundata and Syringodium isoetifolium against Sitophilus oryzae and Sitophilus zeamais. International Journal of Herbo Medica, Vol. - 2 (3) 87 - 94. ISSN 2394 - 692X.

33. Aswathi Elizabeth Mani, V. Bharathi and Jamila Patterson.2012. Antibacterial Activity and Preliminary Phytochemical Analysis of Sea Grass Cymodocea rotundata. International Journal of Microbiological Research, ISSN 2079-2093.

34. Abdel-Hamid A. Hamdya, Walaa S. A. Mettwallya, Mohamed Abou El Fotouh, Benjamin Rodriguez, Ahmed I. El-Dewanya, Sayed A. A. El-Toumy, and Ahmed A. Hussein. 2012. Bioactive Phenolic Compounds from the Egyptian Red Sea Seagrass Thalassodendron ciliatum. Z. Naturforsch. 67 c, $291-296$.

35. Magdy M.D. Mohammed, Abdel-Hamid A. Hamdy, Nabaweye M. El-Fiky, Walaa S.A. Mettwallyc, Ahmed A. El-Beih \& Nobuyuki Kobayashia.2014. Anti-influenza a virus activity of a new dihydrochalcone diglycoside isolated from the Egyptian seagrass Thalassodendron ciliatum (Forsk.) den Hartog, Taylor \& Francis.

36. N. Pushpa Bharathi, P. Amudha AND V. Vanitha. 2016. SEAGRASS - novel marine nutraceuticals. Int J Pharm Bio Sci; 7(4): (B) 567 - 573, ISSN 0975-6299. 
37. Danaraj Jeyapragash1, Ponnnambalam Subhashini, Subramaniyan Raja, Karmegam Abirami and Thirunavukarassu Thangaradjou. 2016. Evaluation of In-vitro Antioxidant Activity of Seagrass: Signals for Potential Alternate Source, Free Radicals and Antioxidants, Vol. 6, pp77-89.

38. Ragupathi Raja Kannan R, Arumugam R, Thangaradjou T, Anantharaman P. 2013. Phytochemical constituents, antioxidant properties and p-coumaric acid analysis in some seagrass. Food Res Int; 54: 12291236.

39. Neelima, C.Sarika, S., Seenivasan, R.2015.Free radical scavenging activity of selected Seagrass from South East Coast of India. International Journal of Advanced Research, Volume 3, Issue 10, 950 - 956, ISSN 23205407.

40. Joko Santoso, Siti Anwariyah, Ria Octavia Rumiantin, Aristi Pramadita Putri, Nabila Ukhty, and Yumiko Yoshie-Stark. 2012. Phenol content, antioxidant activity and fibers profile of four tropical seagrass from Indonesia. Journal of Coastal Develpopment, Vol 15, Number 2: 189-196 ISSN: 1410-5217.

41. Ragupathi Raja Kannan Rengasamy, Arumugam Rajasekaran, GrignonDubois Micheline \& Anantharaman Perumal.2012. Antioxidant activity of seagrass of the Mandapam coast, India. Pharmaceutical Biology, 50(2): 182-187, ISSN 1388-0209. 